\title{
Studies of the Precambrian basement in the Agto-Nordre Strømfjord area, central West Greenland
}

\section{Niels $\varnothing$. Olesen and Kai Sørensen}

During the summers 1966 to 1969 geological mapping on the Agto 1:100 000 map sheet (fig. 23) was undertaken by Erling Bondesen and students mainly from Aarhus University (for example, see Bondesen, 1966, 1970). During this period the north-western part of the region was completed - amounting to about half of the total map sheet area. In 1975 the second stage of this mapping commenced, sponsored by GGU, and it is planned to complete the map sheet in four summers.

Besides the completion of this map sheet and the understanding of the regional geology, the mapping has the function of being used in the training of students at Aarhus University and the specific purpose of investigating in detail the Nordre Strømfjord shear zone (Bak et al., 1975a \& b). In 1975, the students involved were Birger F. Hansen, Flemming Mengel and Terkel S. Olsen assisted by Flemming Getreuer, Anders Rehkopff and Birgitte Rørdam.

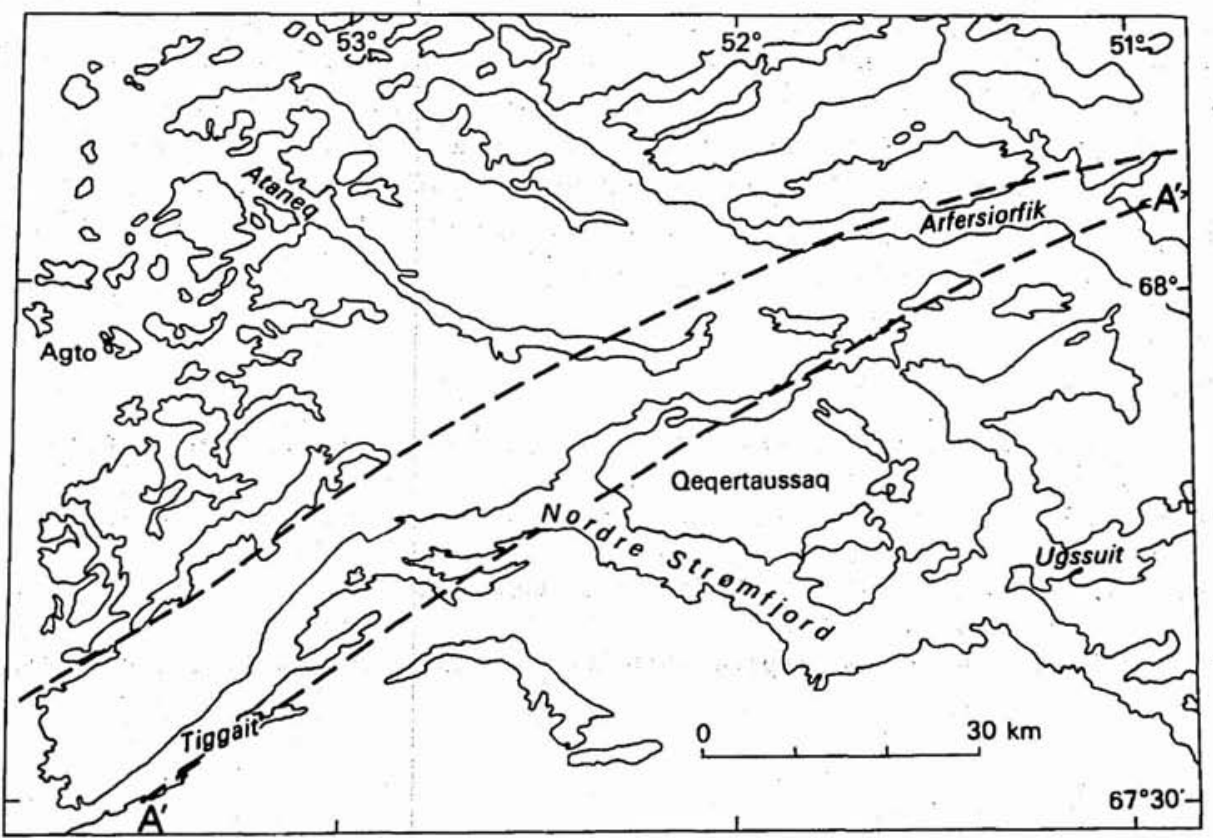

Fig. 23. Sketch map of the Agto map sheet (1:100 000), central West Greenland, defined by latitudes $67^{\circ} 30^{\prime} \mathrm{N}$ and $68^{\circ} \mathrm{N}$ and west of $52^{\circ} \mathrm{W}$. The dashed lines indicate the tentative boundaries of the Nordre Strømfjord shear zone. 


\section{Main results of the mapping}

The shear zone model of Bak et al. (1975b) was confirmed by the summers' mapping, but it was also revealed, that what was believed to be the south-eastern boundary of the zone (line $\mathrm{A}-\mathrm{A}^{\prime}$ of fig. 23) is in fact an internal boundary within a zone wider than hitherto assumed. Both at Tiggait and at western Qeqertaussaq a narrow shear zone was found approximately two kilometres south of the main one. This shear zone, at least 1 to $2 \mathrm{~km}$ wide, is a logical continuation of the larger one to the north, as it rotates pre-existing planar structures into a consistently southward-dipping position with a strike very close to that found in the major zone. This discovery means that the shear zone as a whole is more symmetrical than originally thought. It is wider and the off-set across it is therefore greater than calculated by Baket al. (1975b). It contains a $2 \mathrm{~km}$ wide zone of seemingly lower strain close to its southern boundary. This increased width is of little consequence for the $10 \mathrm{~km}$ estimate of the crustal level difference from the coast to the ice, as the increased opening angle of the shear zone is balanced by increased width.

\section{Short reconnaissance into Arfersiorfik}

The authors made a 3 day reconnaissance trip into Arfersiorfik aimed at locating the shear zone boundaries at the most accessible localities between the ice and the eastern boundary of the Agto map sheet, and to examine the diorite body marked on the 1:500 000 Søndre Strømfjord - Nûgssuaq map sheet at the head of Arfersiorfik. The northern boundary of the latter is well defined but the southern boundary is difficult to locate since the diorite body possesses a tectonite fabric both outside and within the shear zone.

\section{Palaeomagnetic sampling}

Dr. G. Beckmann from the Physics Department, University of Newcastle, sampled cores for palaeo-pole determinations at ten localities between the coast and the ice from the mouth of Nordre Strømfjord to Ugssuit, for the purpose of applying an independent test of the tectonic model of differential uplift of the crust.

\section{References}

Bak, J., Grocott, J. Korstgård, J., Nash, D., Sørensen, K. \& Watterson, J. 1975a: Tectonic implications of Precambrian shear belts in western Greenland. Nature Lond. 254, 566-569.

Bak, J., Korstgård, J., \& Sørensen, K. 1975b: A major shear zone within the Nagssugtoqidian of West Greenland. Tectonophysics 27, 191-209.

Bondesen, E. 1966: Research on the high-metamorphic complexes of the Agto area. Rapp. Gronlands geol. Unders. 11, 19-21.

Bondesen, E. 1970: Field work in the Agto-Nordre Strømfjord region. Rapp. Grønlands geol. Unders. 28, 17-19.

Laboratoriet for Endogen Geologi, Geologisk Institut, Aarhus University, Ole Worms Alle, 8000 Aarhus C, Denmark. 